
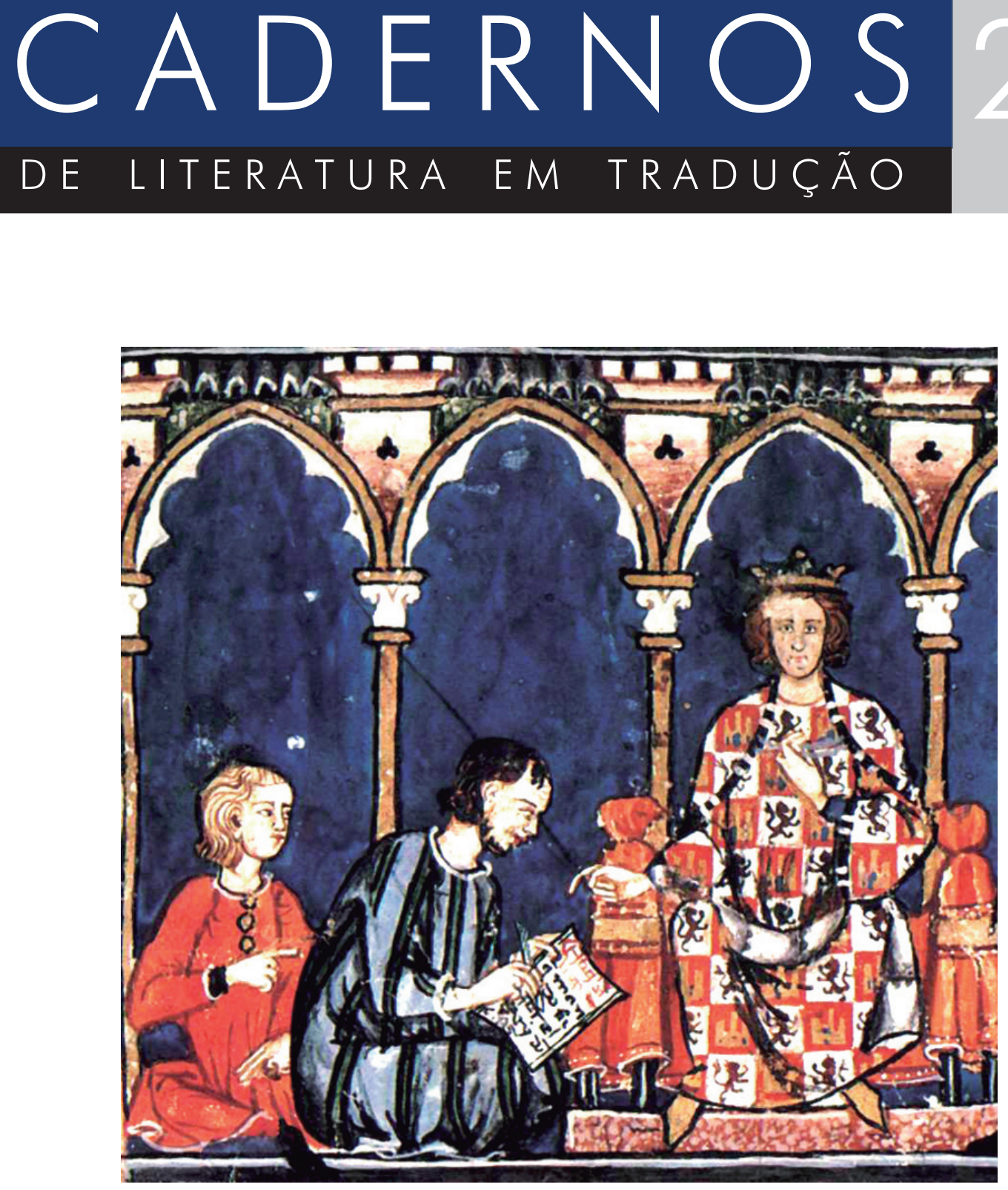

Tradutores da chamada Escola de Toledo com Afonso $X$ de Castela 


\title{
O caso de Clyde Griffiths, de Erwin Piscator: Theodore Dreiser em versão épica
}

\author{
Fernando Bustamante ${ }^{1}$
}

Resumo: Este artigo apresenta a tradução do prólogo da peça inédita em português The Case of Clyde Griffiths, de Erwin Piscator, baseada no romance An American Tragedy, de Thedore Dreiser. Além da tradução, apresenta uma breve trajetória da escrita e de duas montagens do texto nos EUA, feitas em 1935 e 1936, bem como a análise de alguns recursos do teatro épico empregados pelo seu dramaturgo. Palavras-chave: Erwin Piscator, teatro épico, Theodore Dreiser, An American Tragedy, dramaturgia épica.

\section{O caso de Clyde Griffiths}

\section{Prólogo}

O NARRADOR está embaixo, em meio à orquestra, à direita, à frente das luzes da ribalta e durante seu discurso ele anda lentamente para a esquerda, tomando seu lugar rapidamente no momento em que a cortina se ergue.

NARRADOR Atenção, senhoras e senhores! Vocês irão ver esta noite uma peça que foi feita a partir de um romance, que seu autor, Theodore Dreiser, chamou de UMA TRAGÉDIA AMERICANA. Mas nós não estamos preocupados com a pura reiteração do romance ou a simples dramatização de seus incidentes. Essa tragédia que vocês verão

1 Doutorando em Letras pelo programa de Estudos Linguísticos e Literários em Inglês da Faculdade de Filosofia, Letras e Ciências Humanas (FFLCH) da USP. Bolsista CAPES. 
essa noite é tão internacional quanto o problema do Contraste de Classes, a Distinção de Classes da qual se origina a história. Nós estamos aqui para resolver um problema matemático que mostra que o destino do homem hoje é tão inexorável e absoluto quanto era seu destino nas antigas tragédias gregas. Nós podemos chamá-lo de A Lei do Trabalho, ou, ainda melhor, do Capital. (A cortina se ergue, música suave)

Duas classes surgiram do Capital. Vocês podem ver que o palco está dividido de acordo com isso. À direita, a terra da Pobreza; à esquerda, a terra das Riquezas. E no centro, sim, no centro está A Terra de Ninguém, na qual os dois lados decidem seus destinos. (A cabeça de CLYDE aparece.)

Aqui vocês veem Clyde Griffiths, o filho de um pobre pastor itinerante que vaga pelas ruas cantando e rezando para trazer a salvação a um mundo pecaminoso. Eles nunca têm nenhum dinheiro; eles vivem dos centavos doados por pessoas piedosas e das vendas de panfletos. Eles desprezam qualquer outra coisa. Eles vivem em um misterioso mundo de sonhos que contrasta tão fortemente com a realidade que até esse menino de doze anos o sente. Ele sente, misturado à tristeza, uma vergonha desdenhosa dos seus pais, de sua origem humilde, suas ideias piedosas, suas roupas gastas e sua própria falta de cultura e impotência.

A FAMÍLIA GRIFFITHS é formada pelo pai, a mãe e três filhos, dois meninos e uma menina. A menina está empurrando um órgão sobre rodas. Eles cantam um hino.

"Olhe para longe das coisas terrenas, Apenas em Deus estão a Verdade e a Salvação”

NARRADOR (continua) Os carros luxuosos, os pedestres bem-vestidos, as vitrines brilhantes, todos despertam em Clyde uma percepção de outro mundo, melhor e mais bonito, e nasce nele o desejo de fugir de seu meio intolerável e se tornar uma parte desse reino fascinante.

À DIREITA a fazenda de ALDEN. À sua frente o velho Alden, sua esposa e sua filha ROBERTA.

NARRADOR À direita vocês veem a fazenda de Alden. São dez da manhã. Uma velha casa em ruínas, com um valor total de cerca de US\$2.400. A fazenda não produz mais do que aproximadamente noventa quilos de batatas, alguns vegetais, um pouco de aveia e comida para uma vaca. Não é o suficiente para prover uma herança para um filho ou um dote para uma filha que vá se casar; mal é o suficiente para prover a família de quatro pessoas. 
ALDEN Você poderia tentar a fábrica de colarinhos dos Griffith. Ouvi falar que estão contratando mais garotas.

ROBERTA Eu vou encontrar algo; não se preocupe.

MÃE Eu detesto ver você partir. Ai, Berta, tome cuidado. E nos escreva sempre.

ROBERTA Ah mãe, você sabe que vou. Não precisa se preocupar. Vai ser difícil pra mim também ir para longe de vocês. Mas o que mais se pode fazer?

ALDEN E não se esqueça do que conversamos! Quando você puder... você sabe... ou nós vamos ter que vender o cavalo.

ROBERTA Sim, sim, eu sei pai. Eu vou mandar alguma coisa pra vocês assim que puder, e vir para casa também, quando puder. Não é longe de Licurgo. A cena se apaga, apenas ROBERTA permanece visivel.

NARRADOR Roberta Alden vai à cidade para ganhar seu pão. Ela parte, deixando muita coisa para trás, e, ah, quanto à sua frente! Talvez ela encontre um emprego na fábrica de colarinhos de Samuel Griffiths, que emprega 1.200 mulheres e garotas, lavando, costurando, estampando, em pé diante das máquinas da sua fábrica. E desse jeito se encontram, em Licurgo, 20 mil, nos Estados Unidos, 3.000.000, e no mundo 200 milhões de mães e filhas separadas de suas famílias, a se entregar a um destino desconhecido, incertas sobre como vão viver a cada dia, sem esperança, tentando sempre assegurar o suficiente para descansar em algum momento no futuro. Aqui à esquerda, na terra da riqueza, está outra jovem.

SONDRA FINCHLEY, vestida para viajar de automóvel, trajando uma roupa cara, está diante de um carro, falando com as pessoas sentadas dentro dele.

SONDRA Papai e mamãe decidiram desistir da casa no Lago Verde e pegar uma em Ponto dos Pinheiros, no Lago Doze. Nós vamos ficar lá esse verão. Ai, estou tão feliz! A casa é bem perto da água, com uma imensa varanda na qual podemos dançar. Não vai ser divino? E papai vai comprar para Stuart uma lancha elétrica de trinta pés.

O NARRADOR interrompe sua fala.

NARRADOR Essa jovem não pertence às 200 milhões. Ela nunca teve que temer pelo seu futuro. Sua única preocupação é atravessar o dia de modo confortável e divertido. Ela nunca pensa de onde vem o dinheiro para suas roupas, seus prazeres, suas festas. Diferente 
de Roberta, ela nunca experimentou a terrível pressão da pobreza. Tudo que ela faz foi perdoado de antemão. O que alguém reputaria como falta de caráter em outros, nela é apenas um capricho ou humor passageiro. Ela não precisa temer nada, já que por trás dela está a sua família, e isso significa US\$1.250.000.

Vocês viram agora três figuras nesta tragédia. O destino de duas delas será decidido no decorrer dessa noite. Mas seus destinos não são apenas algo pessoal, individual. É um destino que foi estabelecido desde o princípio, estabelecido pela Distinção de Classes. Duas garotas de igual beleza, e entre elas Clyde Griffiths, que, na invejável e difícil situação que se seguirá, deve escolher entre elas. Tal como em um problema matemático se colocam esses elementos centrais: duas garotas, uma pobre e outra rica, e um homem, ele próprio pertencente a uma classe sem posses, mas levado pelas circunstâncias a tentar um salto de uma classe a outra, um perigoso salto por meio do qual ele... não, vocês verão no decorrer da noite.

As garotas à esquerda e direita desaparecem. A luz se apaga durante o último discurso, e quando a direita e a esquerda estão escuros, o centro se ilumina e mostra CLYDE como um carregador em um hotel. Ele está conversando, de costas para o público.

NARRADOR Clyde primeiro conseguiu um emprego em uma sorveteria. Mas a vida o impeliu a seguir subindo. Seu sonho foi alimentado pelos homens e mulheres elegantes que ele servia. Mas ele ganhava apenas seis dólares por semana, dos quais ele dava três a sua família. Isso não era o suficiente. Ele queria estar mais próximo da vida. Ele obtém um emprego como carregador em um grande hotel.

VOZ DE UM MENINO Você não me disse uma vez que tinha um parente na indústria de colarinhos perto de Nova Iorque?

CLYDE Sim, meu tio, Samuel Griffiths. Ele tem uma grande fábrica em Licurgo. Por quê?

VOZ DO MENINO Você o conhece?

CLYDE Não, eu nunca o vi na vida. Só ouvi minha mãe e meu pai falarem dele.

VOZ Bem, eu acho que ele está aqui nesse hotel. É ele ali, vindo na nossa direção. (Um distinto homem idoso entra na luz).

SAMUEL GRIFFITHS Por favor, cuide dessa carta para mim. Mas entregue-a pessoalmente. Aqui... (dá uma gorjeta para CLYDE). 
CLYDE Ah, não, obrigado... me desculpe perguntar, mas o senhor é o Sr. Griffiths?

SAMUEL Sim.

CLYDE Bom, acho que sou seu parente, Sr. Griffiths.

SAMUEL Mas quem é você?

CLYDE O meu pai é Asa Griffths, seu irmão.

SAMUEL Sim, Asa Griffiths é meu irmão. Você é filho dele? Seu nome é...?

CLYDE Clyde. Clyde Griffiths.

SAMUEL Isso é mesmo uma surpresa. Você é filho do Asa! Você deve saber que não tenho notícias do seu pai há mais de vinte e cinco anos. Ele ainda está vivo?

CLYDE Sim, Sr. Griffiths. Meus dois pais estão vivos.

SAMUEL Seu pai ainda está vinculado ao trabalho religioso?

CLYDE Sim, eles têm agora uma missão em Denver... um tipo de albergue.

SAMUEL Bem. E você? Gosta do seu trabalho aqui?

CLYDE Não muito. Eu ganho o suficiente, mas a forma de ganhar não é muito divertida. Não é o tipo de trabalho que eu tinha em mente para mim. Mas eu nunca tive uma oportunidade de aprender algo de valor. Meus pais estava sempre se mudando de cidade em cidade. E então eu quis ganhar meu próprio sustento. Eu gostaria de entrar em algo que pudesse me dar um futuro.

SAMUEL E você pensou em algum tipo especial de trabalho?

CLYDE Certa vez minha mãe queria que eu escrevesse e lhe perguntasse se o senhor teria alguma utilidade para mim na sua fábrica. Mas eu fiquei com receio que o senhor não gostasse de que eu lhe escrevesse. (pausa) Eu suponho que não tenha nada na sua fábrica que o senhor pudesse querer confiar a mim? 
SAMUEL Eu estou muito interessado no que você me disse. E gostaria de fazer algo por você. Mas eu preciso pensar sobre isso primeiro. Não posso dizer que sim ou que não agora. De toda forma, não poderia pagar tanto quanto você está recebendo aqui.

CLYDE Ah, isso não importa.

SAMUEL É possível também que você não goste da nossa fábrica. Ou que você não se adeque ao trabalho.

CLYDE Então o senhor só teria que me mandar embora. Mas desde que ouvi falar a seu respeito e da sua grande fábrica eu senti que gostaria de estar ligado a ela.

SAMUEL Lamento não ter tempo agora, mas eu vou ficar mais dois dias e vou pensar a respeito. Talvez eu possa fazer algo por você. Eu não sei ainda. Mas vou lhe dizer, e quem sabe o veja em Licurgo.

A CENA se apaga - Fim do prólogo. 


\section{The Case of Clyde Griffiths}

\section{Prologue}

The SPEAKER stands downstairs, in Orchestra, at right, before the footlights and during his talk walks slowly left, taking his place quickly the moment the curtain rises.

SPEAKER Attention, ladies and gentlemen! You will see this evening a play that has been made from a novel, which its author, Theodore Dreiser, calls AN AMERICAN TRAGEDY. But we are concerned not so much with the naked reiteration of the novel or the simple dramatization of its incidents. This tragedy that you will see this evening is as international as the problem of Class-Contrast, Class-Distinction from which the story arises. We are here to solve a mathematical problem that shows that the fate of man today is as inexorable and absolute as was his fate in the old Greek tragedies. We might term it The Law of Labor, or better yet, of Capital. (Curtain rises, to soft music)

Two classes have sprung from Capital. You can see that the stage is accordingly divided. On the Right, the land of Poverty; on the left, the land of the Riches. And in the center, yes, in the center, lies No Man's Land, in which both sides work out their destinies. (The head of CLYDE appears)

Here you see Clyde Griffiths, the son of a poor, itinerant preacher who wanders the streets singing and praying to bring salvation to a sinful world. They never have any money; they live on the pennies of pious people and the sale of tracts. They scorn anything else. They live in a misterious dream world that contrasts so strongly with reality that even this twelve-year-old boy feels it. He feels, mingled with sorrow, a contemptuous shame for his parents, their humble origin, their pious ideas, their shabby clothes, and his own lack of culture and his impotence.

The GRIFFITHS FAMILY consists of father and mother and three children, two boys and a girl. The girl is pushing a harmonium on wheels. They sing a hymn

"Turn your eyes from earthly things,

Only in God is Truth and Salvation."

SPEAKER (continues) The luxurious motor-cars, the well-dressed pedestrians, the glittering shop-windows, all arouse in Clyde a realization of another, better and more beautiful, world, and the desire is born in him to flee his intolerable surroundings and become a part of this fascinating realm. 
RIGHT The Alden farmbouse. In front of it, old man Alden, his wife and daughter ROBERTA.

SPEAKER At the right you see the farm of Alden's. It is ten O'Clock in the morning. An old dilapidated house with four rooms, its total worth about $\$ 2400$. The farm yields no more than about two-hundred weight of potatoes, a few vegetables, some oaths and feed for a cow. Not enough to provide an inheritance for a son or a dowry for a marriageable daughter; barely sufficient to provide for the family of four.

ALDEN You might try the Griffiths collar factory. I hear they are taking on more girls.

ROBERTA I'll find something; don't worry.

MOTHER I hate to see you go. Oh, Berta, be careful, won't you. And write to us regularly.

ROBERTA Oh, mother, you know I will. You needn't worry. It will be hard for me, too, to go away from you. But what else is there to do.

ALDEN And don't forget what we talked about! When you can manage... you know... otherwise we'll have to sell the horse.

ROBERTA Yes, yes, I know, father. I'll send something as soon as I can, and come home, too, when I can. It's not far from Lycurgus.

The scene fades; only ROBERT A remains visible.

SPEAKER Roberta Alden goes to the city to earn her living. She goes, leaving much behind her, and oh, how much ahead of her! Perhaps she will find a place in the collar factory of Samuel Griffiths, who employs all of twelve hundred women and girls, washing, sewing, stamping, standing before the machines of his factory. And so, in Lycurgus, there are 20,000, in the United States 3,000,000, and in the whole world 200 million, mothers and daughters torn from their families, to deliver themselves to an unknown fate, uncertain of how they will live from day to day, without hope, ever trying to secure sufficiente enough to rest at some future time. Here on the left, in the land of wealth, is another young woman.

SONDR A FINCHLEY, dressed for motoring, wearing an expensive wrap, stands before an automobile, talking to the people sitting within.

SONDRA Papa and mama have decided to give up the house at Greenlake and take one at Pinepoint on Twelfth Lake. We'll be staying there this summer. Oh, I'm so glad! The 
house is right on the water, with a huge veranda on which we can dance. Won't that be heavenly! And papa is going to buy Stuart a thirty-foot electric motorboat.

\section{SPEAKER breaks into her conversation}

SPEAKER This young woman does not belong to the 200 million. She has never experienced "Life-fear". Her one concern is to get through the day entertainingly and confortably. She never thinks of where the money comes from for her clothes, her pleasures, her parties. Unlike Roberta, she has never known the terrible pressure of poverty. All that she does was excused from the beginning. What one would deem characterless in others is in her a merely whim or mood. She needs to fear nothing, since behind her stands her family, and that means $\$ 1,250,000$.

You have now seen three figures in this tragedy. The fate of two of them will be worked out in the course of this evening. But their destiny is not only and individual, personal thing. It is a destiny that was ordained from the beginning ordained by Class-Distinction. Two girls of equal beauty, between them Clyde Griffiths, who, in the enviable, difficult situation which will follow, must choose between them. As in a mathematical problem stand these chief figures two girls, the one poor, the other rich, and one man, himself belonging to a propertyless class, but driven by circumstances to attempt the leap from one class to another, a dangerous leap by which he... no, you will see in the course of the evening.

The girls left and right disappear. The light fades during the last speech, and when right and left are dark, the center grows light and discloses CLYDE as a hotel bellboy. He is talking, with his back to the audience.

SPEAKER Clyde first found employment at a soda fountain. But life impelled him to move upward. His dream was fed by the fashionable men and women he served. But he earned only six dollars a week, of which he gave three to his family. That was not enough. He wanted to get nearer to life. He secures a place as a bellboy in a great hotel.

VOICE OF A BOY Didn't you once tell me that you had a relative in the collar industry in the neighborhood of New York?

CLYDE Yes, my uncle, Samuel Griffiths. He owns a large factory in Lycurgus. Why?

BOY'S VOICE Would you know him?

CLYDE No, I never saw him in all my life. I've only heard my mother and father speak of him. 
VOICE Well, I believe he's here in this hotel. That's him over there coming this way. (A distinguished elderly man walks into the light).

SAMUEL GRIFFITHS Please take charge of this letter for me. But deliver it personally. Here... (gives CLYDE a tip)

CLYDE Oh, no, thanks... Excuse the question, but are you Mr. Griffiths?

SAMUEL Yes.

CLYDE Well, I believe I am related to you, Mr. Griffiths.

SAMUEL But who are you?

CLYDE My father is Asa Griffiths, your brother.

SAMUEL Yes, Asa Griffiths is my brother. You are his son? Your name...?

CLYDE Clyde. Clyde Griffiths.

SAMUEL This is indeed a surprise. You Asa's son! You must know that I haven't heard of your father for over twenty-five years. Is he still living?

CLYDE Yes, Mr. Griffiths. Both my parents are living.

SAMUEL Is your father still connected with religious work?

CLYDE Yes, they now have a mission in Denver... sort of a little lodging house.

SAMUEL So. And you? Do you like your work here?

CLYDE Not very much. I earn enough, but the way of earning it isn't much fun. It's not the kind of work I had in mind for myself. But I never had an opportunity to learn anything worthwhile. My parents were always moving from city to city. And then I wanted to earn my own living. I'd like to get into something that would have a future for me.

SAMUEL Have you thought of any special kind of work? 
CLYDE Once my mother wanted me to write and ask you if you could use me in your factory. But I was afraid you wouldn't like me writing you. (pause) I suppose there's nothing in your factory you would want to trust me with?

SAMUEL I'm deeply interested in what you've told me. And I'd like to do something for you. But I must think it over first. I can't say yes or no at this time. Anyway, I wouldn't be able to pay you as much as you're getting here.

CLYDE Oh, that doesn't matter.

SAMUEL It's possible, too, that you wouldn't like it in your factory, or that you wouldn't suit the work.

CLYDE Then you would only have to let me go. But ever since I heard of you and your great factory, I've had the feeling that I wanted to be connected with it.

SAMUEL Sorry that I haven't the time now, but I'm staying another two days and will think it over. Perhaps I can do something for you. I don't know yet. But I'll let you know, and maybe I'll see you in Lycurgus.

SCENE fades out - End of Prologue 


\section{Nota do tradutor}

The Case of Clyde Griffiths é uma adaptação feita originalmente para o idioma alemão pelo diretor e dramaturgo Erwin Piscator a partir do romance estadunidense de Theodore Dreiser, An American Tragedy, de 1925. O livro de Dreiser, por sua vez, foi baseado em uma história real de um jovem que assassina sua namorada grávida e acaba condenado à morte, em um caso judicial que - como sói acontecer nos Estados Unidos - tornou-se um "espetáculo midiático", chocando e atraindo as atenções do grande público por meio da cobertura da imprensa.

O volumoso romance de Dreiser, com mais de 800 páginas, torna-se um best seller, e em 1927 é traduzido ao alemão sob o título Eine amerikanische tragodie roman, por Marianne Schön, e publicado pela editora Berlin P. Zsolnay. A partir daí uma primeira adaptação do romance para o teatro em alemão seria aventada sob o auspício de Lena Goldschmidt ${ }^{2}$, escritora alemã que já havia trabalhado com a tradução de obras anteriores de Dreiser para a língua germânica.

Após algumas frustradas tentativas de levar aos palcos a adaptação, Dreiser decide procurar um nome muito conhecido no teatro alemão para integrar o projeto, que é o de Erwin Piscator. O diretor e dramaturgo havia se tornado um dos nomes de maior destaque no teatro na Alemanha da década de 1920, tendo sido o principal responsável pela revolução das concepções cênicas e dramatúrgicas que ficariam conhecidas sob o nome de teatro épico, cuja essência era de repensar o fazer teatral a partir do enfoque histórico e social da luta de classes, trazendo em seu bojo uma profunda transformação em todos os âmbitos, que ia desde a dramaturgia até os aspectos técnicos da cena - sendo estes últimos aqueles pelos quais Piscator é frequentemente lembrado, tais como a introdução do uso de projeções cinematográficas, mas que constituem apenas um entre tantos recursos empregados por ele na busca de uma ruptura estético-política da arte teatral. Junto a Bertolt Brecht - que foi profundamente influenciado pelo amigo e parceiro, chegando a integrar e produzir junto a ele em seu coletivo teatral Piscator ocupou um papel central na renovação teatral ligada ao movimento revolucionário de trabalhadores na Alemanha, em um movimento que ocorria paralelamente a uma transformação muito semelhante do teatro na Rússia após a revolução soviética, com nomes como Vsevólod Méierhold e Vladímir Maiakóvski como expoentes.

2 A grafia do nome da autora e tradutora é encontrada em diferentes formas nas diversas fontes, ora aparecendo como "Lena", ora como "Lina". 
Piscator aceita o trabalho proposto por Dreiser, com o condicionante de ter a liberdade de interferir no texto produzido por Golschmidt. Ainda que ele seja recorrentemente e injustamente apenas lembrado por seu trabalho como diretor, uma marca indelével do trabalho de Piscator era a de sempre retrabalhar o texto dramatúrgico de forma radical para que ele estivesse de acordo com os preceitos de suas concepções teatrais, o que não raras vezes lhe rendeu desentendimentos com os autores, que nem sempre concordavam com suas modificações. Um associado de Piscator, em carta a Dreiser de 23 de marco de 1929, afirma que ele considera a versão de Goldschmidt promissora, mas que era "sehr einfaches Theater" (um teatro muito simples) (WENTZ, 1961, p. 368). Por fim, acordam que Piscator seria o responsável pela dramatização, enquanto Goldschmidt atuaria como agente e representante de Dreiser. Ainda assim, por vezes o nome de Goldschmidt consta também como co-autora do texto, e desconhecemos até que ponto sua primeira escrita determinou o resultado final da peça.

O acirramento do clima político na Alemanha, somado ao cenário econômico também muito difícil, fizeram com que a estreia da peça fosse recorrentemente adiada. Da inviabilidade de financiar o projeto à prisão de Piscator por motivos políticos - mas sob o pretexto de uma dívida fiscal - são muitos os percalços que inviabilizam a montagem. Assim, do projeto inicial de estreá-la em 1930, adia-se para janeiro de 1931, depois para novembro do mesmo ano, em seguida abril de 1932, e, finalmente, quando uma viagem a trabalho de Piscator para a URSS acaba se transformando em um exílio para escapar à ascensão nazista na Alemanha, o projeto acaba tendo que ser abandonado.

As adaptações feitas por Piscator e Goldschmidt não haviam sido as primeiras a levar o romance de Dreiser para a dramaturgia: já em 1926, um texto de autoria de Patrick Kearney fora encenado nos palcos da Broadway. A contraposição entre, por um lado, a peça de Kearney e a adaptação cinematográfica de 1931, com roteiro de Samuel Hoffenstein e direção de Josef Von Sternberg, e por outro lado a peça de Erwin Piscator e a frustrada tentativa de adaptação cinematográfica feita por Sergei Eisenstein - rejeitada pelo estúdio que a produziria em detrimento da versão de Hoffenstein/Sternberg - é muito expressiva do tipo de debate suscitado pelas distintas interpretações do romance de Dreiser, e joga luz sobre a intenção de Piscator com seu texto de caráter épico, cujos elementos retomaremos adiante.

A versão em inglês da peça teve sua estreia no Hedgerow Theatre, em Rose Valley, na Pensilvânia, em 20 de abril de 1935, sob direção de Jasper Deeter. Foi o próprio Dreiser que, tendo tomado conhecimento do texto escrito por Piscator, e querendo encená-lo nos EUA, procurou Deeter - cujo trabalho conhecia da 
época do Provincetown Theatre, em Nova Iorque, entre 1919 e 1921. Essa versão foi bem-sucedida, tendo permanecido no repertório do Hedgerow Theatre até 1938, com 69 apresentações; entre 1947-48 retornou para mais 44 apresentações.

Em artigo para o New York Times, Dreiser teceu elogios à peça de Piscator, dizendo-se "enormemente impressionado" por ela, e considerando-a superior à versão "semi-melodramática" de Kearney (DREISER, 1935 apud NEWLIN, 2003, p. 5). Em 1936, o texto ganharia nova montagem na Broadway, encenado pelo Group Theatre. Pela incompatibilidade entre as concepções do grupo e as presentes no texto de Piscator, pautadas no teatro épico, a peça foi um fracasso, tendo apenas 19 apresentações antes de ser retirada de cartaz.

O trecho aqui traduzido, correspondente ao prólogo da peça escrita por Piscator, é suficientemente ilustrativo a respeito dessa diferença. Enquanto o filme de Sternberg, por exemplo, apresenta uma visão extremamente melodramática da história, procurando comover o público, o texto de Piscator está ancorado na concepção de um teatro épico, da qual ele foi pioneiro na Alemanha dos anos 1920 a partir de um trabalho contínuo em desenvolver e pensar uma intervenção teatral ligada à luta dos trabalhadores. O objetivo de Piscator é demonstrar que é a sociedade de classes e sua inevitável injustiça a verdadeira culpada pelo crime, e não Clyde Griffiths, cujo verdadeiro crime teria sido o de trair sua classe ao tentar ascender socialmente sob os favores de seu tio.

Alguns recursos fundamentais expressam essa concepção e traduzem, no plano dramatúrgico, a intenção do autor, tal como a presença do narrador como elemento de fundamental importância na peça. Desde sua primeira fala, o narrador expõe ao público a intenção de abordar a história de Clyde não como um drama individual, mas como um "problema matemático" capaz de expressar as grandes questões sociais de seu tempo, demonstrando como "a lei do Capital" governa a vida das mulheres e homens, e fundando na divisão de classes o lastro para o desenvolvimento trágico do enredo.

Além do narrador, que ao longo de toda a peça irá ressaltar os aspectos sociais e econômicos que demarcam a posição das personagens, outros recursos são empregados por Piscator para acentuar tais elementos. Vemos, por exemplo, como a divisão do espaço cênico entre a Terra da Pobreza, a Terra da Riqueza e a Terra de Ninguém está colocada em função de ressaltar esse sentido.

Assim, podemos ver que o que interessa a Piscator é justamente realizar o movimento oposto daquele apontado pela adaptação de Sternberg: o que importa, como afirma o narrador, é mostrar que não se trata de um drama individual de um casal estadunidense, mas de uma história que retrata o sentido mais profun- 
do de uma sociedade dividida em classes. Clyde, ambicionando "subir na vida" e abandonar sua própria classe em nome de ser incluído na classe proprietária, estará disposto a tudo. Isso, longe de ser retratado por Piscator como um "desvio de caráter", será apontado como o tipo de ação que é incentivada e promovida por essa sociedade, na qual cada um deve lutar sem escrúpulos pelo seu sucesso individual. O "pecado" de Clyde, de acordo com essa visão em que o "vale-tudo" é legitimado pelo capitalismo, não seria o de aplicar esse princípio, mas sim o de fazê-lo de forma ineficaz, tendo seu crime apontado e descoberto. Fosse ele um membro da classe dominante, seus crimes seriam encobertos e perdoados. Como aponta o narrador ao introduzir Sondra Finchley, "Tudo que ela faz foi perdoado de antemão. O que alguém reputaria como falta de caráter em outros, nela é apenas um capricho ou humor passageiro."

Assim, a peça de Piscator é um excelente exemplo das concepções do teatro épico, bem como uma evidência de que sua renovação estilística está a serviço de apresentar uma visão política de crítica à sociedade de classes.

O trabalho com a peça de Piscator faz parte de minha pesquisa de doutorado, realizada sob a orientação de Maria Silvia Betti no programa de Estudos Linguísticos e Literários em Inglês na Faculdade de Filosofia, Letras e Ciências Humanas da Universidade de São Paulo.

\section{Referências bibliográficas}

DREISER, Theodore. An American Tragedy. Signet Classics, 2010.

NEWLIN, Keith (Edit). A Theodore Dreiser Encyclopedia. Westport: Greenwood Press, 2003.

PISCATOR Erwin. "Case of Clyde Griffiths" in: The "lost" group theatre plays. Volume 3. CreateSpace Independent Publishing Platform, 2013.

WENTZ, John C., An American Tragedy as Epic Theater: The Piscator Dramatization. p. 368. In: Modern Drama, Volume 4, Number 4, Winter 1961: University of Toronto Press. p. 365-376. 